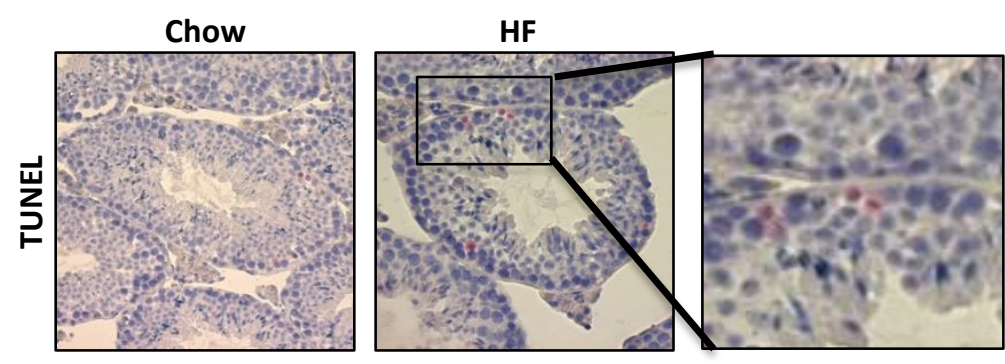

Intratesticular lipid parameters

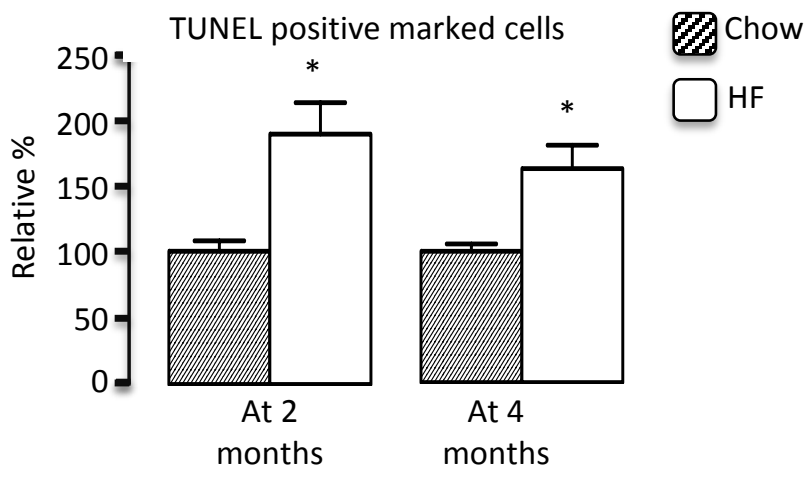

\section{2 months}

Cholesterol

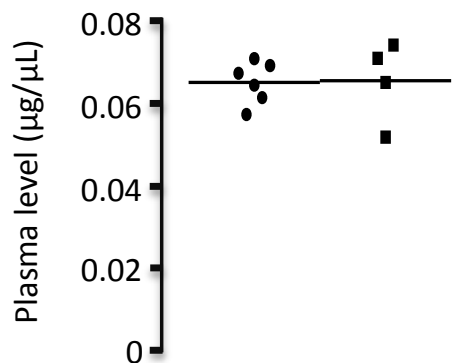

Intratesticular lipid parameters
Cholesterol ester

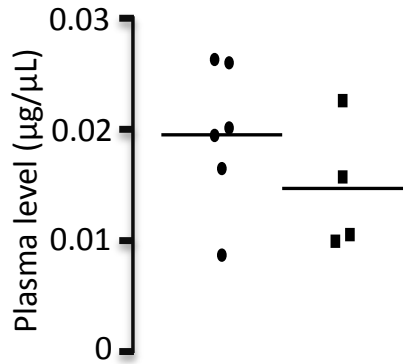

Triglycerides

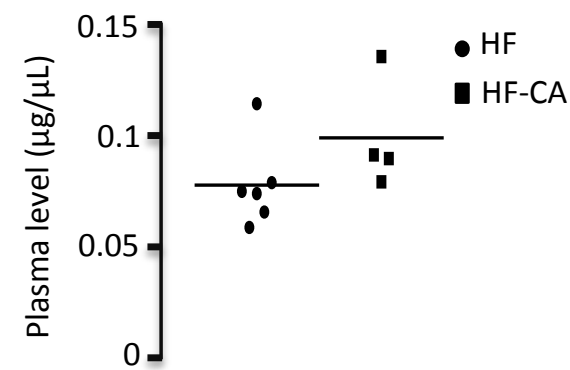

4 months

Cholesterol

Cholesterol ester

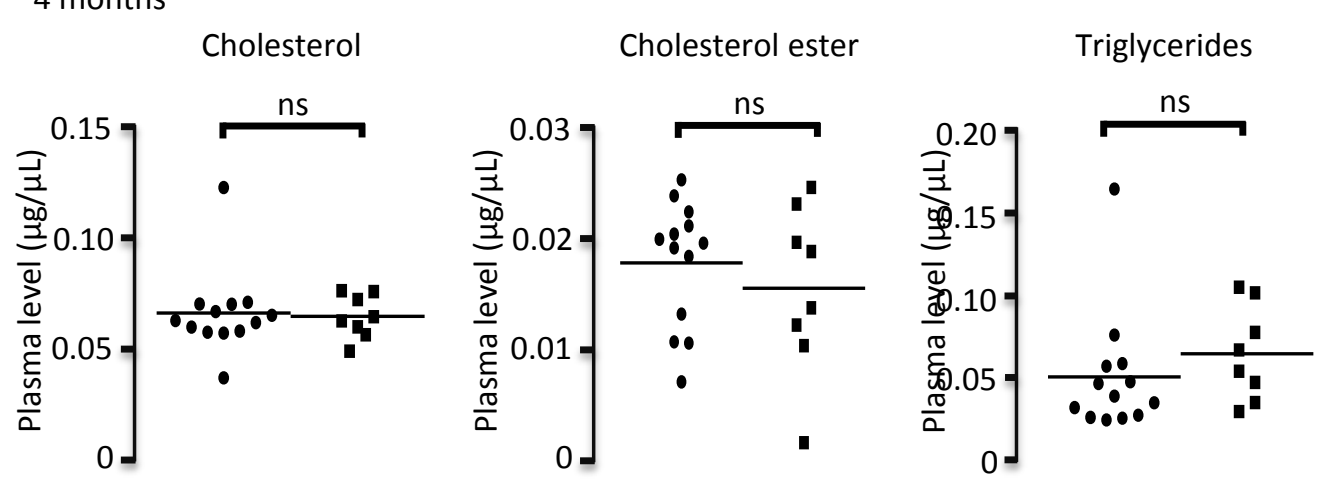

Suppl 3.
- HF

- HF-CA 